$1 \% \mathrm{D} 0 \% 94 \% \mathrm{D} 0 \% \mathrm{BE} \% \mathrm{D} 0 \% \mathrm{~B} 2 \% \mathrm{D} 1 \% 96 \% \mathrm{D} 0$ $\% \mathrm{~B} 4 \% \mathrm{D} 0 \% \mathrm{BD} \% \mathrm{D} 0 \% \mathrm{~B} 8 \% \mathrm{D} 0 \% \mathrm{BA} \% 202003-$ $2018 \% 20 \% \mathrm{D} 0 \% \mathrm{BE} \% \mathrm{D} 0 \% \mathrm{~B} 4 \% \mathrm{D} 0 \% \mathrm{BD} \% \mathrm{D} 0$ $\% \mathrm{BE} \% \mathrm{D} 0 \% \mathrm{~B} 9 \% 20 \% \mathrm{D} 0 \% \mathrm{BA} \% \mathrm{D} 0 \% \mathrm{BD} \% \mathrm{D} 0$ \%B8\%D0\%B3\%D0\%BE\%D0\%B9_n.pdf

9. Ukrzaliznycja, gholovnyj informacijnyj analitychnyj centr «RAIL Insajder [Ukrzaliznytsia, RAIL Insider's Chief Information and Analytical Center] URL: https://www. railinsider.com.ua/

10. Ukrzaliznycja $\quad-2018$. Integhrovanyj zvit AT «Ukrzaliznycja» (richnyj zvit) [Ukrzaliznytsia - 2018. Integrated report of Ukrzaliznytsia JSC (annual report)] URL: https://www.uz.gov.ua/

files/file/Book\%20UZ_18_Final(new).pdf

11. Roslik I. Iznos puti $i$ otsutstvie kachestvennogo remonta [Depreciation of the track and lack of quality repairs] URL: сети.https://biz.censor.net.ua/ r3146735https://biz.censor.net.ua/r3146735

12. Ukrinform. Muljtimedijna platforma innomovlennja Ukrajiny [Ukrinform.

Multimedia platform of foreign language of

Ukraine]

URL:

https://www.ukrinform.ua/rubric-

economy/2787347-ukrzaliznica-rozpocala-

proces-zakupivli-vagoniv-za-kosti-ebrr.html

13 Strateghija AT «Ukrzaliznycja»

[Strategy of JSC "Ukrzaliznytsya"] URL:

https://www.uz.gov.ua/files/file/about/documen ts $/ \%$ D0\%A1\%D1\%82\%D1\%80\%D0\%B0\%D

$1 \% 82 \% \mathrm{D} 0 \% \mathrm{~B} 5 \% \mathrm{D} 0 \% \mathrm{~B} 3 \% \mathrm{D} 1 \% 96 \% \mathrm{D} 1 \% 8 \mathrm{~F}-$

5-Typography $\% 20($

$\% \mathrm{D} 1 \% 83 \% \mathrm{D} 0 \% \mathrm{BA} \% \mathrm{D} 1 \% 80)$.pdf

$14 U 2018$ roci Ukrzaliznycja investuje 18,4 miljjardy ghryvenj u rukhomyj sklad ta prodovzhytj strukturni reformy [In 2018, Ukrzaliznytsia will invest UAH 18.4 billion in rolling stock and continue structural reforms]. URL:: http://uprom.info/. Національний промисловий портал.

\title{
ЦИФРОВА ТРАНСФОРМАЦІЯ ЗАЛІЗНИЧНОГО ТРАНСПОРТУ ЯК ФАКТОР ЙОГО ІННОВАЦІЙНОГО РОЗВИТКУ
}

\author{
Токмакова І.В., д.е.н, професор (УкрДУЗТ), \\ Чередниченко О.Ю., к.е.н., доцент, професор (Інститут підготовки \\ юридичних кадрів для СБ Украӥни Національного юридичного університету \\ імені Ярослава Мудрого), докторант (УкрДУЗТ), \\ Войтов І.М., ст. викладач, \\ Паламарчук Я.С., махістр (УкрДУЗТ)
}

3 метою забезпечення інновачійного розвитку залізничного транспорту досліджено передумови його ичфрової трансформації. Розкрито зміст ичифровізаиіі та її переваги для бізнесу. Акиентовано увагу на активізації иифрових перетворень на залізничному транспорті країн ЕС. Виявлено стан впровадження IКТ на залізничному транспорті та визначено основні напрямки реалізації циифрових перетворень в вітчизняній залізничній галузі на технологічному і організаційному рівнях.

Ключові слова: цифрова трансформації, цифрові переваги, інноваційний розвиток, свропейська система управління залізничним рухом, залізничний транспорт.

(C) Токмакова I.B.,

Чередниченко О.Ю.,

Войтов I.M.,

Вісник економіки транспорту і промисловості № 68, 2019

Паламарчук Я.С. 


\title{
ЦИФРОВАЯ ТРАНСФОРМАЦИЯ ЖЕЛЕЗНОДОРОЖНОГО ТРАНСПОРТА КАК ФАКТОР ЕГО ИННОВАЦИОННОГО РАЗВИТИЯ
}

\author{
Токмакова И.В., о.э.н, профессор (УкрГУЖТ), \\ Чередниченко А.Ю., К.э.н., доцент, профессор ( Институт подготовки \\ юридических кадров для СБ Украины Национального юридического \\ университета имени Ярослава Мудрого), докторант (УкрГУЖТ), \\ Войтов И.Н., ст. преподаватель, \\ Паламарчук Я.С., магистр (УкрГУЖТ)
}

\begin{abstract}
С иелью обеспечения инновационного развития железнодорожного транспорта исследованы предпосылки его цифровой трансформации. Раскрыто содержание ичифровизации и ее преимущества для бизнеса. Акиентировано внимание на активизации циифровых преобразований на железнодорожном транспорте стран СС. Выявлено состояние внедрения ИКТ на железнодорожном транспорте и определень основные направления реализаџии циифровых преобразований в отечественной железнодорожной отрасли на технологическом и организационном уровнях.
\end{abstract}

Ключевые слова: цифровая трансформации, цифровые преимущества, инновационное развитие, европейская система управления жселезнодорожным движением, железнодорожный транспорт.

\section{DIGITAL TRANSFORMATION OF RAILWAY TRANSPORT AS A FACTOR OF ITS INNOVATIVE DEVELOPMENT}

Tokmakova I.V., Doctor of Economics, Associate Professor, (USURT) Cherednychenko O.U., PhD in Economics (Juridical Personnel Training Institute for the Security Service of Ukraine, Yaroslav Mudryi National Law University) Voytov I. M., Senior lecturer (USURT), Palamarchuk Ya. S., master (USURT)

In order to ensure the innovative development of railway transport, the prerequisites for ensuring its digital transformation are studied. The content of digitalization and its advantages for business are revealed. In particular, it is established that digitalization in the business sector contributes to technological progress by optimizing and improving the accuracy and efficiency of work. Attention is focused on the activation of digital transformations in the railway transport of the EU countries and it is revealed that the main standard for the introduction of digital innovations is ERTMS, which includes the European train control system and GSM-R mobile networks to ensure communication between trains and radio units. Now ERTMS projects, which are usually called digital Railways, are developing in the UK, Germany and Norway and other countries. The state of ICT implementation in railway transport is revealed and it is determined that now realizuemih measures for the development of information and communication tools is extremely insufficient for the formation of digital advantages of railway transport.

It is concluded that the impetus for the digital transformation of the railway industry are three main components. The first is the digital counterparts of objects, which are models that can display the physical state of a process in real time. The second is solutions that ensure the integration of all enterprise information systems on a single digital platform. The

Вісник економіки транспорту і промисловості № 68, 2019 
third component is the development of the industrial Internet, which allows you to connect objects and individuals to a single network and provides data exchange. Digital transformation, which is based on these three components, can lead not only to improved reliability and quality of rail transport, but also to positive economic effects-reducing transaction costs, productivity growth, etc.

The main directions of digital transformation in technological and organizational aspects are defined. It is found that the organizational context of the digital transformation of railway transport is based on: partnership and cooperation; changes in HR-strategy and culture; improvement of management quality; changes in organizational structure.

Keywords: digital transformation, digital advantages, innovative development, european railway traffic management system, railway transport.

Постановка проблеми та іiї зв'язки 3 науковими чи практичними завданнями. Забезпечення сталого розвитку i конкурентоспроможності залізничного транспорту в умовах сьогодення напряму залежить від впровадження проривних інноваційних рішень, які відповідають сучасним трендам науково-технічного прогресу. При цьому основним напрямом трансформації суспільства нині виступає цифровізація, яка в економічній сфері грунтується на тотальному впровадженні інформаційно-комунікаційних технологій та орієнтована на глибоке перетворення продуктів, бізнес- і операційної моделі підприємств та процесів взаємодії між користувачами і постачальниками продукції і послуг. Переваги цифровізації пов'язані 3 динамічними підходами використання даних i створенням цифрових платформ, що забезпечує об'єктивність і швидкість рішень та позитивну співпрацю. Для залізничного транспорту України, функціонування якого у теперішній час супроводжується кризовими явищами через критичний стан залізничної інфраструктури і проблеми організаційно-управлінського характеру, цифровізація $\epsilon$ вирішальним фактором інноваційного розвитку. Адже цифрові інновації дозволять кардинально змінити методи роботи і підвищити ефективність бізнес-процесів підприємств залізничного транспорту, що підтверджує актуальність і своєчасність обраної теми статті.

Аналіз останніх публікацій. Проблеми розвиту залізничного транспорту $\epsilon$ об'єктом вивчення у наукових працях таких вчених, як Дикань В. Л., Корінь М. В. [1], Обруч Г. В. [2], Овчиннікова В. О. [3], Токмакова I. В. [4] та багатьох інших. Питання цифровізації залізничного транспорту висвітлено в наукових публікаціях Компанієць В. В. [5], Купріяновського В. П., Суконнікова Г. В., Ярцева Д. І., Кононова В. В., Сінягова С. А., Наміота Д. Є., Добриніна А. П. [6], Скалозуба В. В., Соловйова В. П., Жуковицького І. В., Гончарова К. В. [7] та інших.

Виділення невирішених частин загальної проблеми. Поряд 3 існуючим теоретичним i практичним внеском вчених в вирішення проблем інноваційного розвитку залізничного транспорту України потребує більш детального вивчення питання його цифровізації в контексті забезпечення інноваційного прогресу i формування конкурентних переваг в сучасних умовах господарювання.

Мета статті полягає в розкритті мотивів i основних інструментів та напрямів цифрової трансформації залізничного транспорту як ключового фактора його інноваційного розвитку.

Виклад основного матеріалу. Цифровізація в сучасному світі $\epsilon$ глобальним процесом, який викликаний стрімким розвитком інформаційних технологій, мікроелектроніки і комунікацій. Процеси цифровізації через зближення різних цифрових технологій призводять до змін у сферах IоT, великих 
масивів даних, хмарних обчислень, робототехніки, штучного інтелекту та 3D друку, які допомагають реагувати на основні прагнення сучасних клієнтів, такі як персоналізація, підвищення безпеки та комфорту, а також енергоефективність та збереження ресурсів.

Цифровізація в бізнес-сфері сприяє технологічному прогресу завдяки оптимізації та підвищенню точності та ефективності роботи. Підприємства швидко замінюють традиційні процеси взаємодії цифровими, використовуючи найсучасніші технології. Нині цифрове перетворення — це бізнес-стратегія, в якій інформаційно-комунікаційні технології забезпечують інновації та креативність, на основі чого компанії отримують новий i кращий досвід для клієнтів. Підприємства, які підтримують зміни і готові до них, а також здатні адаптуватися до більш гнучких моделей роботи, мають як ніколи великий потенціал успіху. Це пов'язано 3 тим, що цифрова трансформація охоплює всі аспекти бізнесу і пропонує ефективні шляхи їх вдосконалення разом 3 розвитком цифрових технологій.

За результатами аналізу більш 400 крупних компаній 3 різних галузей, проведеного спільно компаніями Capgemini Consultingи MIT Sloan Management [8], підприємства, які активно використовують цифрові технології та нові методи управління (цифрові лідери Digirati), в середньому на $26 \%$ прибутковіше своїх конкурентів. Більш консервативні компанії (Digital Conservatives), які покращують тільки менеджмент, отримують дадаткових 9 \% до прибутку. Організації, які багато інвестують у цифрові технології, але при цьому приділяють мало уваги управлінню (послідовники цифрової моди — Digital Fashionistas), не здатні отримувати синергетичний ефект і створювати значну додаткову цінність на основі цифрових додатків. Вони мають фінансові показники на 11 \% нижче. I, нарешті, компанії, що недостатньо використовують як потенціал цифрових технологій, так i потенціал управління (початківці Digital Beginners), мають прибуток менше в середньому на $24 \%$. Такі можливості успішної цифрової трансформації.

\section{Мотивуючим}

фактором

цифровізації є і ризики, які виникають для підприємств, що не ініціювали своєчасно зростання своєї цифрової зрілості. Підприємства і загалом галузі, які в найближчому майбутньому випадуть 3 процесу цифрової трансформації, опиняться на периферії. Це стосується i залізничного транспорту.

Глобальна цифровізація вже охопила залізниці багатьох країн. Основним стандартом іi впровадження $\epsilon$ європейська система управління залізничним рухом (ERTMS), що включає європейську систему управління поїздом (ETCS) i мобільні мережі GSM-R для забезпечення зв'язку між поїздами i радіоблоками. Проєкти ERTMS, що як правило називаються цифровими залізницями, активно розвиваються у Великобританії, Німеччині і Норвегї та інших країнах. Вельми цікавою $\epsilon$ майбутня схема залізничних коридорів TEN-T на базі ERTMS (рис. 1), яка вже більше нагадує схему міського метро, ніж залізничних ліній.

Проєкти ERTMS вказують, що інтелектуалізація та цифровизація повинні охоплювати три фундаментальних складових перевізного процесу на залізничному транспорті: організацію перевезень; рухомий склад; технічні засоби інфраструктури.

Натомість залізничний транспорту України, незважаючи на наявний позитивний досвід впровадження інформаційно-комунікаційних технологій, загалом залишається осторонь сучасних цифрових трансформацій.

Напрямок інформаційних технологій АТ «Укрзалізниця» наразі забезпечує безперервну інформаційну підтримку з питань організації перевізного процесу, прийняття управлінських рішень, обслуговування клієнтів залізничного транспорту. Основні показники 
IT-ресурсів АТ «Укрзалізниця» у 2018 р. такі: програмно-апаратні комплекси рівня АТ «Укрзалізниця»та регіональних філій (залізниць) - 22 од.; функціональні сервери - понад 1,6 тис. од.; кількість робочих місць (ПК) - понад 50 тис. од.; обладнання мереж передачі даних та локальних обчислювальних мереж (маршрутизатори, комутатори) - понад 10 тис. од.; понад 148 централізованих автоматизованих систем; корпоративний веб-портал ЄКІП УЗ - 25000 користувачів; близько 31,5 тис. абонентів корпоративної електронної пошти [10].

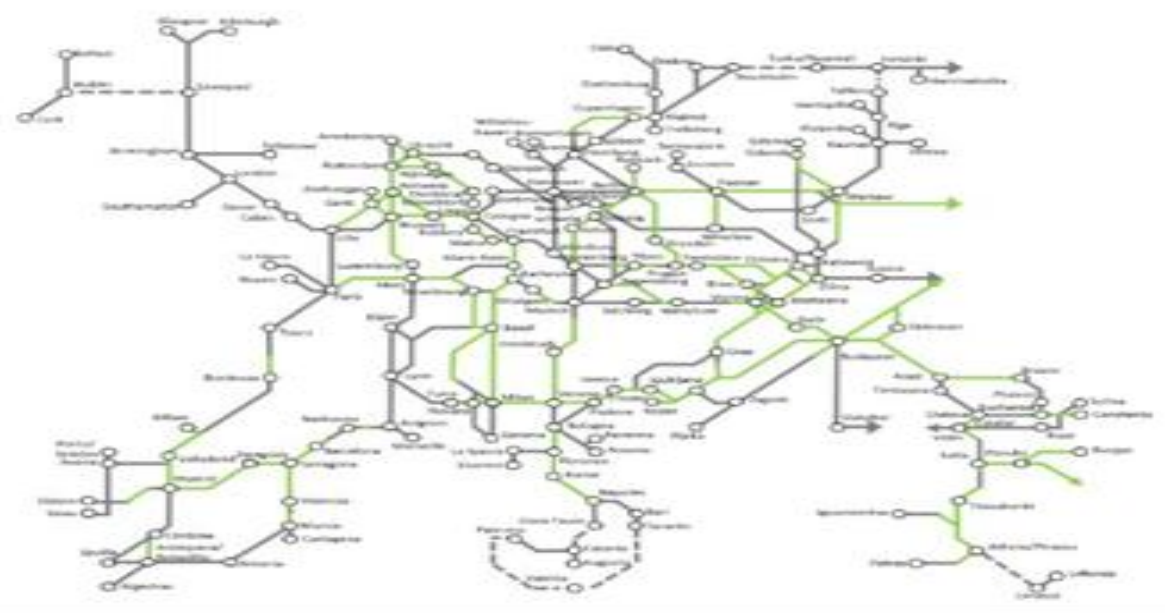

Puc. 1. Схема залізничних коридорів TEN-T на базі ERTMS [9]

Напрямком інформаційних технологій АТ «Укрзалізниця» за 2018 рік забезпечено: продаж 55885651 квитків на пасажирські поїзди дальнього сполучення, зокрема через електронні канали обслуговування (сайт booking.uz.gov.ua та агентська мережа) 27998033 квитків, що на $28 \%$ більше ніж у 2017p.; повністю в електронному вигляді оформлено 1079726 перевізних документів на вантажні перевезення у всіх видах сполучення, зокрема у внутрішньому сполученні оформлено 525610 електронних перевізних документів; зареєстровано в електронній картотеці 20375 клієнтів; системами інформаційної безпеки було виявлено та локалізовано більше 2,5 млн подій інформаційної та кібербезпеки; центром сертифікації ключів сформовано 36265 особистих ключів електронного цифрового підпису [10].

Наразі вищезазначених заходів 3 розвитку інформаційно-комунікаційних інструментів вкрай недостатньо для формування цифрових переваг залізничного транспорту.
Слід вказати, що 3 метою цифрової трансформації вітчизняного залізничного транспорту розроблено дорожню карту для АТ «Укрзалізниця» [11]. Однак на думку спеціалістів вона має значні недоліки через невірний вибір пріоритетів, що обумовлює необхідність розгляду основних положень з реалізації цифрових інструментів в залізничній галузі.

Варто констатувати, що цифрові перетворення в сучасних компаніях грунтуються на можливості отримання інформаційно-комунікаційного ефекту. Досягти останнього можна, пройшовши наступні 3 стадії: 1) автоматизація перенесення завдань 3 персоналу на пристрої та електронні системи для зберігання, обробки і подальшої передачі; 2) цифровізація - оптимізація процесів 3 метою їх пристосування до умов електронної економіки; 3) цифрова трансформація - зміна всієї системи управління бізнесом: від методів виробництва до економічної стратегії підприємства).

Для цифрових перетворень 
залізничної галузі наразі виділяють чотири ключові важеля: цифрові дані, які після збору і аналізу забезпечують кращі прогнози i рішення; системи автоматизації, які збільшують швидкість, знижують частоту появи помилок i експлуатаційні витрати; зв'язність, яка синхронізуе ланцюжок поставок i скорочує інноваційні цикли; цифровий доступ клієнтів, який дозволяє компаніям пропонувати клієнтам прозорість і нові послуги [9].

Поштовхом для цифрової трансформації залізничної галузі виступають три основних компонента. Перший - це цифрові двійники об'єктів, що представляють собою моделі, здатні в режимі реального часу відображати фізичний стан того або іншого процесу. Другий - рішення, що забезпечують інтеграцію всіх інформаційних систем підприємства на єдиній цифровій платформі. Прикладом можуть служити системи управління життєвим циклом (PLM), системи управління ресурсами підприємства (ERP), системи управління взаємовідносинами 3 клієнтами (CRM) та iн. Нарешті, третій компонент - розвиток індустріального Інтернету, який дозволяє підключати об'єкти i фізичних осіб до єдиної мережі і забезпечує обмін даними. Цифрова трансформація, в основі якої ці три складові, здатна привести не тільки до підвищення надійності та якості залізничних перевезень, але i до позитивних економічних ефектів скорочення транзакційних витрат, зростання продуктивності і т. д.

В дорожній карті цифровізації АТ «Укрзалізниця» [11] визначено перелік інструментів, які необхідні для забезпечення цифрової трансформації. Їх перелік подано на рис. 2.

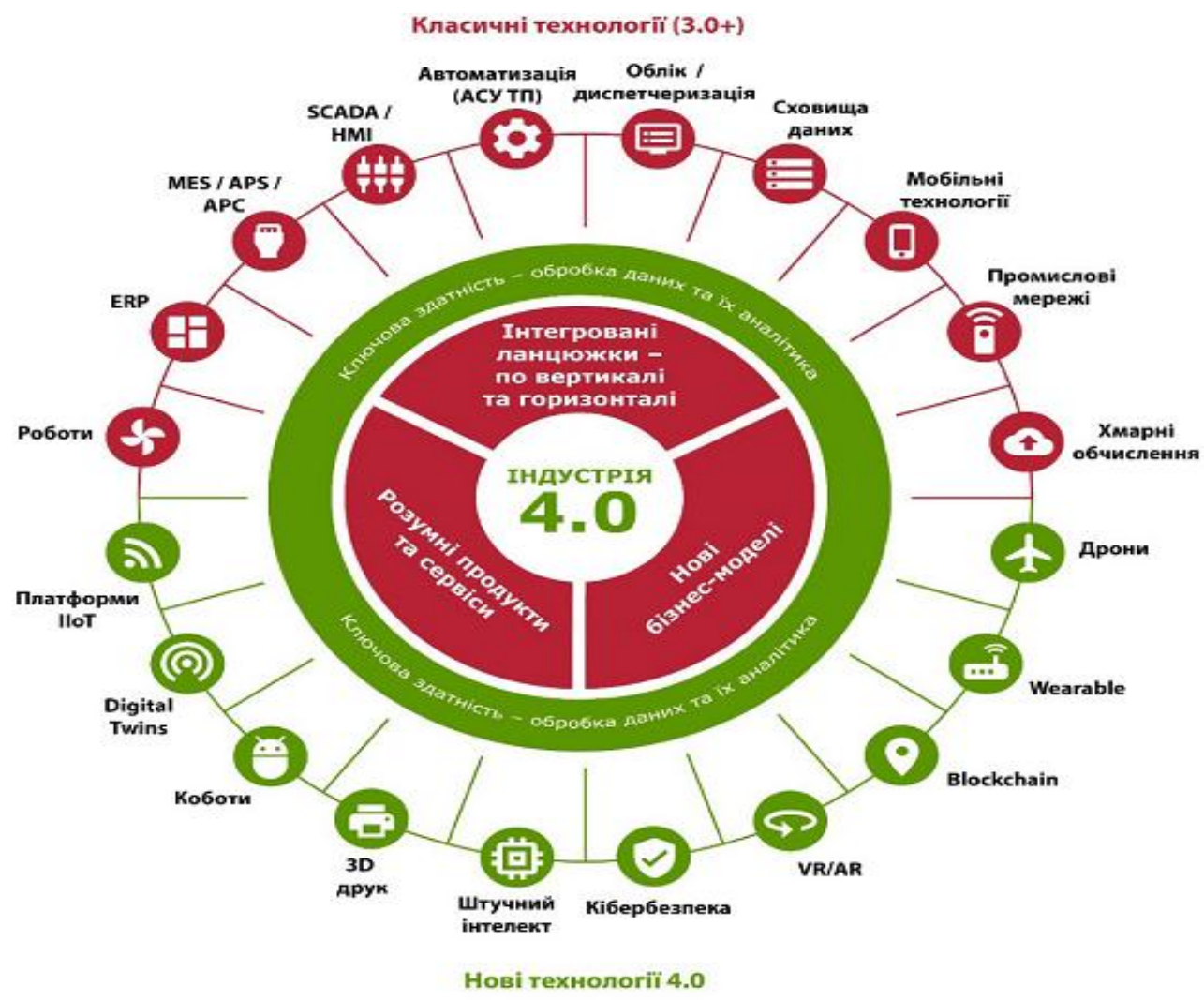

Рис. 2. Класичні та нові ичифрові інструменти для впровадження на залізничному транспорті

При цифрофізації залізничного реалізації - організаційний i транспорту слід врахувати дві рівня iї технологічний, що подано на рис. 3. 


\begin{tabular}{|c|c|c|c|c|c|}
\hline \multicolumn{6}{|c|}{ Технологічний рівень } \\
\hline \multicolumn{2}{|l|}{ Взаємодія з клієнтами } & \multicolumn{2}{|c|}{ Управління перевезеннями } & $\begin{array}{c}\text { Управління станційною } \\
\text { роботою }\end{array}$ & $\begin{array}{c}\text { Управління } \\
\text { інфраструктурою }\end{array}$ \\
\hline \multicolumn{2}{|c|}{$\begin{array}{c}\text { мобільні пристрої та функціональні } \\
\text { додатків, що забезпечують вибір } \\
\text { параметрів подорожі: швидкість, } \\
\text { комфорт та інші індивідуальні умови; } \\
\text { системи доповненої реальності в } \\
\text { проїздах і на вокзалах; } \\
\text { системи планування надання послуг і } \\
\text { планування перевезень на базі } \\
\text { аналізу поведінки клієнтів з } \\
\text { використанням великих даних; } \\
\text { електронні кабінети; } \\
\text { електронні торговельні майданчики; } \\
\text { інтелектуальні системи управління } \\
\text { вокзалами }\end{array}$} & \multicolumn{2}{|c|}{$\begin{array}{c}\text { динамічні системи управління } \\
\text { перевізним процесом з } \\
\text { використанням штучного } \\
\text { інтелекту; } \\
\text { системи моніторингу стану } \\
\text { локомотива в реальному режимі } \\
\text { часу; } \\
\text { системи обслуговування тягових } \\
\text { одиниць на основі даних } \\
\text { моніторингу і діагностики; } \\
\text { системи автоматичного ведення з } \\
\text { можливістю віддаленого } \\
\text { контролю і управління; } \\
\text { системи контролю стану вагона в } \\
\text { русі з передачею інформації }\end{array}$} & $\begin{array}{c}\text { системи автоматичного } \\
\text { здійснення маневрової } \\
\text { роботи; } \\
\text { системи автоматичного } \\
\text { здійснення маневрової } \\
\text { роботи; } \\
\text { системи автоматичного } \\
\text { здійснення сортування; } \\
\text { безпаперова взаємодія; } \\
\text { системи комплексного } \\
\text { автоматичного планування } \\
\text { ресурсів }\end{array}$ & $\begin{array}{c}\text { системи автоматизації } \\
\text { діагностики стану колії й } \\
\text { технічних засобів; } \\
\text { системи автоматизації } \\
\text { процесів ремонту та } \\
\text { обслуговування } \\
\text { інфраструктури на основі } \\
\text { високоточних } \\
\text { координатних методів; } \\
\text { системи управління } \\
\text { ресурсами на базі } \\
\text { єдиного цифрового опису } \\
\text { інфраструктури }\end{array}$ \\
\hline \multicolumn{6}{|c|}{$\sqrt{2}$} \\
\hline \multicolumn{6}{|c|}{ Продукування інновацій } \\
\hline \multicolumn{6}{|c|}{$\longdiv { \square }$} \\
\hline \multicolumn{6}{|c|}{ Організаційний рівень } \\
\hline $\begin{array}{c}\text { Партнерство і } \\
\text { колаборації } \\
\text { Створення і розвиток } \\
\text { платформ для взаємодії з } \\
\text { партнерами. Цифрове } \\
\text { партнерство стає одним з } \\
\text { важливих чинників } \\
\text { масштабування }\end{array}$ & \multicolumn{2}{|c|}{$\begin{array}{l}\text { HR- стратегія і культура } \\
\text { Підвищення кваліфікації і } \\
\text { залучення співробітників на } \\
\text { основі розвитку цифрової } \\
\text { культури і мислення. Разом } \\
\text { з новими технологіями } \\
\text { приходять і нові посади }\end{array}$} & \multicolumn{2}{|c|}{$\begin{array}{c}\text { Якість управління } \\
\text { Впровадження цифрових } \\
\text { інструментів з метою підвищення } \\
\text { швидкості забезпечення } \\
\text { управлінською інформацією, їі } \\
\text { деталізації та достовірності, } \\
\text { підвищення продуктивності } \\
\text { управлінської праці }\end{array}$} & $\begin{array}{c}\text { Організаційні структури } \\
\text { Нові підрозділили: центри } \\
\text { цифрових компетенцій, } \\
\text { відділи об'єднаних даних, } \\
\text { змішані групи } \\
\text { розробників і виробників } \\
\text { Dev-Ops. тощо }\end{array}$ \\
\hline
\end{tabular}

Рис. 3. Основні напрями циифрової трансформації на залізничному транспорті

Як вказує рис. 3, основою технологічних рішень цифровізації $\epsilon$ розвиток інтелектуальної системи управління залізничним транспортом, яка орієнтована на комплексну автоматизацію основних процесів планування i диспетчерського управління перевізним процесом, а також на управління знаннями, і застосовує онтологічну модель елементів інфраструктури та технологічних процесів. Тобто 3 технологічних позицій цифрову залізницю можна визначити як сукупність цифрових технологій i методів опису інфраструктури, рухомого складу, перевізного процесу i технологій управління рухом, забезпечення безпеки та утримання інфраструктури, які орієнтовані на досягнення принципово нових автоматизованих методів планування, диспетчерського управління рухом, ресурсами і обслуговування.

$$
3 \text { організаційних позицій }
$$
цифровізація залізничного транспорту потребує впровадження сукупності бізнесмоделей, транспортних послуг і засобів їх автоматизації, об'єднаних єдиними принципами цифровізації всіх фізичних активів i процесів підприємств залізничного транспорту та їх інтеграція у світову екосистему перевезень.

Організаційний контекст цифрових трансформації залізничного транспорту потребує впровадження інноваційних рішень за такими напрямами.

1. Партнерство i колаборації. Цифровізація нерозривно пов'язана із створенням i розвитком платформ для взаємодії 3 партнерами. Нині цифрове 
партнерство стає одним 3 важливих чинників масштабування.

2. HR-стратегія i культура. Забезпечення цифрової зрілості вимагає постійного підвищення кваліфікації і залучення співробітників на основі розвитку цифрової культури і мислення. У цифровізованому середовищі разом 3 новими технологіями 3'являються i нові посади.

3. Якість управління. Впровадження цифрових інструментів дозволяє підвищити швидкість забезпечення управлінською інформацією, її деталізацію та достовірність i сприяє підвищенню продуктивності управлінської праці.

4. Організаційні структури. Для реалізації проєктів цифровізації необхідні нові підрозділили, серед яких центри цифрових компетенцій, відділи об'єднаних даних, змішані групи розробників i виробників Dev-Ops, тощо.

Висновок.

Таким

цифровізація в сучасному
глобальним пвіті $\epsilon$
процесом, який
відкриває

чином, дорогу до інноваційних способів розвитку підприємств і дозволяє отримати конкурентні переваги на основі максимального врахування потреб клієнтів, а також через забезпечення енергоефективності та збереження ресурсів. За допомогою сучасних цифрових технологій можна досягти значно більшої ефективності в організації роботи вітчизняного залізничного транспорту, що потребує розроблення i впровадження комплексу цифрових інновацій організаційного i технологічного характеру. До першочергових завдань технологічного напрямку слід віднести впровадження інформаційнокомунікаційних технологій в систему організації перевезень, в рухомий склад i технічні засоби інфраструктури. Необхідно створити єдиний комплекс на базі цифрового локомотива, цифрової інфраструктури та інтелектуальної диспетчеризації, що сприятиме організація цифрової інтеграції і взаємодії рухомого складу, інфраструктурного комплексу та центру організації перевезень для об'єднання їх у загальну систему 3 метою оптимізації процесів управління рухом. Поряд 3 цим необхідно враховувати, що нині цифрові перетворення $\epsilon$ бізнесстратегією, реалізація якої можлива на основі партнерства i колаборацій при розбудові цифрових платформ, розвитку цифрових компетенцій i культури персоналу, впровадження цифрових інструментів підвищення якості управління та трансформації організаційні структури підприємств залізничного транспорту відповідно до цифрових змін в основних і забезпечуючих бізнес-процесах.

\section{ПЕРЕЛІК ВИКОРИСТАНИХ ДЖЕРЕЛ}

1. Дикань В. Л. Розвиток високошвидкісного руху в Україні на основі формування виробничо-логістичних кластерів / В. Л.Дикань, М. В. Корінь // Збірник наукових праць УкрДУЗТ, - 2015. Вип. 154. - С. 98-103

2. Обруч Г. В. Забезпечення розвитку потенціалу конкурентоспроможності вагонобудівних підприємств України: дис. ... канд. екон. наук: 08.00.04 «Економіка та управління підприємствами (за видами економічної діяльності)». Український державний університет залізничного транспорту. Харків, - 2017. - 265 с.

3. Овчиннікова В. О. Стратегічне управління розвитком залізничного транспорту України: монографія. Х.: УкрдУЗТ, - 2017. - 427 с.

4. Токмакова I. В. Адаптивна система управління інноваційним розвитком залізничного транспорту України / I.B. Токмакова // Вісник економіки транспорту і промисловості. 2017. - № 57. - С. 137-143.

\section{5. Компаниец}

B. B.

Концептуальный анализ перспектив цифровизации экономики и железнодорожного транспорта./ В. В. Компаниец // Вісник економіки транспорту і промисловості. - 2018. - № 62. - C. 197-200.

Вісник економіки транспорту і промисловості № 68, 2019 


\section{6. Куприяновский}

Цифровая железная дорога - целостная информационная модель как основа цифровой трансформации / В. П. Куприяновский, Г. В. Суконников, Д. И. Ярцев, В. В. Кононов, С. А. Синягов, Д. Е. Намиот, А. П. Добрынин // International Journal of Open Information Technologies. 2016. - T. 4, - №. 10. - С. 32-42.

$$
\text { 7. Скалозуб В. }
$$

I. lohistychnykh klasteriv. [Development of high-speed traffic in Ukraine on the basis of the formation of production and logistics clusters]. Zbirnyk naukovykh prats UkrDUZT, 2015, no. 154 , pp. $98-103$

2 Obruch H. V. Zabezpechennia rozvytku potentsialu konkurentospromozhnosti vahonobudivnykh pidpryiemstv Ukrainy [Ensuring the development of the competitiveness potential of freight car building enterprises of Ukraine] : dys. ... kand. ekon. nauk: 08.00.04 «Ekonomika ta upravlinnia pidpryiemstvamy (za vydamy ekonomichnoi diialnosti)». Ukrainskyi derzhavnyi universytet zaliznychnoho transportu. Kharkiv, 2017. 265 p.

3 Ovchynnikova V. O. (2017) Stratehichne upravlinnia rozvytkom zaliznychnoho transportu Ukrainy [Strategic management of railway transport development in Ukraine] : monohrafiia. Kharkiv: UkrDUZT. (in Ukrainian)

4 Tokmakova I. V. Adaptyvna systema upravlinnia innovatsiinym rozvytkom zaliznychnoho transportu Ukrainy. [Adaptive management system of innovative development of railway transport in Ukraine]. Visnyk ekonomiky transportu i promyslovosti. 2017, no. 57, pp.137-143.

5 Kupriyanovskij V. P., Sukonnikov G. V., Yarcev D. I., Kononov V. V., Sinyagov S. A., Namiot D. E., Dobrynin A. P. Cifrovaya zheleznaya doroga - celostnaya informacionnaya model' kak osnova cifrovoj transformacii. [Digital railway-holistic information model as the basis of digital transformation]. International Journal of Open Information Technologies. 2016. T. 4, no. 10, pp. 32-42.

6 Kompaniec V. V. Konceptual'nyj analiz perspektiv cifrovizacii ekonomiki i zheleznodorozhnogo transporta. Visnyk ekonomiky transportu i promyslovosti.. 2018. no. 62, pp. 197-200.

7 Skalozub V. V., V. P. Solov'ev, I. V. Zhukovickij, K. V. Goncharov. (2013) Intellektual'nye transportnye sistemy zheleznodorozhnogo transporta (osnovy innovacionnyh tekhnologij): posobie.
1 Dykan V. L., Korin M. V. Rozvytok vysokoshvydkisnoho rukhu $\mathrm{v}$ Ukraini na osnovi formuvannia vyrobnycho- 
[Intelligent railway transport systems (accessed: 11.11.2019)

(fundamentals of innovative technologies)]. D.

: Izd-vo Dnepropetr. nac. un-ta zh.-d. transp. im. akad. V. Lazaryana. (in Ukrainian).

8 The Digital Advantage: How Digital Leaders Outperform Their Peers in Every Industry. Capgemini Consulting, MIT Sloan Management. URL: https://www.capgemini.com/wp-content/uploads/2017/07/the_digital_advantage_ how_digital_leaders_outperform_their_peers_i n_every_industry.pdf (accessed: 20.01.2019).

9 Intehrovanyi zvit 2018: dlia investoriv: [Integrated report 2018: for investors]. AT «Ukrzaliznytsia» : ofitsiinyi sait. Available at: https://uz.gov.ua/about/investors/issuer/.
10 Pokusaev O. N., Klimov A. A., Kupriyanovskij V .P., Morhat P. M., Namiot D. E. Cifrovaya zheleznaya doroga Evropy - ot ERTMS do iskusstvennogo intellekta. [Europe's digital railway - from ERTMS to artificial intelligence] International Journal of Open Information Technologies. 2019. Vol. 7, no.7, pp.90-119.

11 Dorozhnia karta tsyfrovoi transformatsii zaliznytsi, versiia APPAU. [Road map for digital transformation the railroad, the version of APPAU]. Rail EXPO : veb-sait. Available at: https://railexpoua.com/novyny/dorozhnyakarta/ (accessed: 5.11.2019)

\title{
УДК 656.025.2
}

\section{ФОРМУВАННЯ СИСТЕМИ МЕНЕДЖМЕНТУ ЯКОСТІ ПАСАЖИРСЬКИХ ПЕРЕВЕЗЕНЬ ШВИДКІСНИМИ ПОЇЗДАМИ}

\author{
Шкуренко О.В., к.е.н., доцент (ДУІТ) \\ Шульгіна А.В., помічник директора (філія УЗШК АТ «Укрзалізниця»)
}

У статті проаналізовано розвиток високошвидкісного руху для пасажирських перевезень. Визначено роль, принщипи та функиії використання швидкісних поӥздів до організації перевезень пасажирів. Основну увагу приділено формуванню системи менеджменту пасажирських перевезень швидкісними поӥздами. Запропоновано на підприємстві впровадити стандарт ISO 9001: 2015, який встановлює критерії системи менеджменту якості $i \epsilon$ єдиним стандартом серії, за яким можливо здійснювати сертифікаиію.

Ключові слова: пасажирські перевезення, ивидкісні поӥзи, стандарти, менеджмент, якість

\section{ФОРМИРОВАНИЕ СИСТМЫ МЕНЕДЖМЕНТА КАЧЕСТВА ПАССАЖИРСКИХ ПЕРЕВОЗОК СКОРОСТНЫМИ ПОЕЗДАМИ}

\author{
Шкуренко О.В., к.э.н., доцент (ГУИТ) \\ Шульгина А.В., помощник директора (филиал УЖСК АО «Укрзализныця»)
}

В статье проанализировано развитие высокоскоростного движения для пассажирских перевозок. Определена роль, принциипь и функции использования скоростных поездов к организачии перевозок пассажиров. Основное внимание уделено формированию системы менеджмента пассажирских перевозок скоростными поездами.

(C) Шкуренко О.B.,

Вісник економіки транспорту і промисловості № 68, 2019

Шульгіна А.В. 